\title{
PARIWISATA BERBASIS MASYARAKAT UNTUK PENINGKATAN PENDAPATAN ASLI DAERAH KABUPATEN KEPULAUAN ANAMBAS
}

\author{
Community-Based Tourism for Local Revenue Improvement Anambas Archipelago \\ District
}

Tinnike Coster ${ }^{1}$, Lala M.Kolopaking ${ }^{2}$, Faroby Falatehan ${ }^{3}$

\begin{abstract}
1Staff Badan Perencanaan Pembangunan Daerah, Kab.Kep Anambas. email: kekecoster@gmail.com
2Staff pengajar Departemen Sains Komunikasi Pembangunan. Fakultas Ekologi Manusia. IPB. email: lalakolopaking@gmail.com

2Staff pengajar Departemen Ekonomi Sumberdaya dan Lingkungan. Fakultas Ekonomi dan Manajemen IPB. email: robie_fa@gmail.com
\end{abstract}

\begin{abstract}
There are several objectives in the study: (1) the potential of tourism and regions support that can meet the needs of the tourists, (2) the forms of community empowerment in the development of community-based tourism and (3) the strategy of the development of community-based tourism to increase local revenues. The potencies of tourism supports that should be improved in the development of Anambas Archipelago tourism are the improvement of infrastructure, both public infrastructure and tourism infrastructure, such as marine transportation and recreational facilities of nautical tourism, which has an average value of 4.93 that means it should be more focused on its development. While the region that can meet the needs of travelers in the development of tourism is located in Siantan district that is in the first rank and becomes the only district in the hierarchy I that is 59.54. The forms of community participation or community empowerment in the development of community-based tourism are in the form of fish farming, the increase of regional typical crafts and foods with the value of 4.79 that is to be developed, and that these activities are usually done by Anambas Archipelago community so that it can be beneficially used and should be developed in order to participate in the development of community-based tourism to generate profits for the government it self in the form of local revenue.
\end{abstract}

Keywords: Tourism, Community, Increase Local Revenues, Tourism

\begin{abstract}
ABSTRAK
Penelitian bertujuan untuk (1) menganalisis sarana prasarana pendukung pariwisata dan wilayah yang dapat memenuhi kebutuhan para wisatawan, (2) Menganalisis pemberdayaan masyarakat dalam pengembangan pariwisata berbasis masyarakat dan (3) Menyusun strategi pengembangan pembangunan pariwisata berbasis masyarakat untuk peningkatan pendapatan asli daerah. Sarana prasarana pendukung pariwisata yang harus ditingkat dalam pengembangan pembangunan pariwisata Kabupaten Kepulauan Anambas adalah peningkatan sarana prasarana umum maupun sarana prasarana bidang pariwisata yaitu transportasi laut dan sarana rekreasi wisata bahari yang memiliki nilai paling tinggi sebesar 4.93 artinya harus lebih difokuskan dalam pembangunannya. Sedangkan untuk wilayah yang dapat memenuhi kebutuhan wisatawan untuk pengembangan pembangunan pariwisata terletak di Kecamatan Siantan yang menempati ranking satu dan menjadi satu-satunya kecamatan yang berada di hierarki I sejumlah 59.54. Bentuk keikutsertaan masyarakat atau pemberdayaan masyarakat dalam pengembangan pembangunan pariwisata berbasis masyarakat yaitu pada pembudidayaan ikan, peningkatan kerajinan dan makanan khas daerah dengan nilai paling tinggi sebesar 4.79, merupakan aktifitas yang sering dilakukan masyarakat Kabupaten Kepulauan Anambas dimana hal tersebut dimanfaatkan dan harus dikembangkan dalam berpartisipasi untuk pengembangan pembangunan pariwisata berbasis masyarakat yang dapat menghasilkan keuntungan bagi pemerintah itu sendiri berupa pendapatan asli daerah.
\end{abstract}

Kata kunci: Pariwisata, Masyarakat, Pendapatan Asli Daerah, Pariwisata 


\section{PENDAHULUAN}

Implementasi pelaksanaan otonomi daerah adalah langkah memberikan kewenangan yang luas, nyata dan memiliki tanggung jawab ke daerah terutama dalam hal mengatur, mengurus, memanfaatkan, serta mengelola berbagai sumber-sumber potensi di daerah. Dengan potensi yang dimiliki, daerah dapat mengembangkannya sehingga memperoleh sumber penerimaan untuk daerah melalui Pendapatan Asli Daerah. Suatu daerah tidak menggantungkan sumber penerimaan daerah dari pemerintah pusat. Daerah mandiri dengan mencari sumber penerimaan yang dihasilkan dari sumber potensi yang dimiliki. Implikasi dari berlakunya Undang-Undang Nomor 32 tahun 2004, memberikan peluang bagi setiap Pemerintah Kabupaten/Kota untuk merencanakan dan mengelola pembangunan daerahnya sendiri, serta partisipasi aktif masyarakat dalam proses pembangunan dari perencanaan, pelaksanaan, monitoring dan evaluasi.

Undang-Undang Nomor 9 Tahun 1990 tentang Kepariwisataan menyatakan bahwa masyarakat memiliki kesempatan yang sama dan seluas-luasnya untuk berperan serta dalam penyelenggaraan kepariwisataan. Dalam rangka proses pengambilan keputusan, pemerintah dapat mengikut sertakan masyarakat melalui penyampaian saran, pendapat dan perimbangan. Pembinaan kepariwisataan diarahkan untuk mewujudkan dan memelihara kelestarian serta keutuhan obyek dan daya tarik wisata, pembinaan kepariwisataan termasuk penyediaan kawasan pariwisata dengan memberikan kesempatan kepada masyarakat setempat untuk ikut serta dalam pembangunan, pengembangan, pengelolaan dan pemilikan kawasan pariwisata.

Laporan Keterangan Pertanggungjawaban Akhir Masa Jabatan Bupati Kabupaten Kepulauan Anambas periode Tahun 2010 sampai dengan Tahun 2015 menyatakan bahwa sektor pariwisata adalah potensi unggulan daerah Kabupaten Kepulauan Anambas, berdasarkan potensi pariwisata yang beragam pula Kabupaten Kepulauan Anambas di jadikan Destinasi Pariwisata Nasional (DPN Natuna Anambas dan sekitarnya) dalam Rencana Induk Pengembangan Pariwisata Nasional (RIPPARNAS) Tahun 2010 - 2025. Berdasarkan hal tersebut sektor pariwisata untuk dapat dikembangkan, memberikan sumber penerimaan bagi pemerintah dan peningkatan perekonomian masyarakat, namun hal ini belum maksimal.

Kabupaten Kepulauan Anambas memiliki potensi unggulan pariwisata. Potensi pariwisata yang dimiliki belum memberikan dampak yang besar terhadap sumber penerimaan daerah begitu pula ekonomi masyarakat, belum memberikan kesejahteraan. Sumber penerimaan terbesar Kabupaten Kepulauan Anambas adalah berasal dari dana bagi hasil yang berasal dari minyak dan gas yang berada diperairan Kepulauan Anambas bukan berasal dari sumber penerimaan potensi unggulan sektor pariwisata. Sumber penerimaan Dana Bagi Hasil mengalami penurunan, dari hal tersebut pemerintah daerah hendaknya dapat mencari sumber penerimaan lain dengan mengembangkan potensi unggulan yang ada. Penerimaan Dana Bagi Hasil daerah disajikan pada pada Gambar 1.

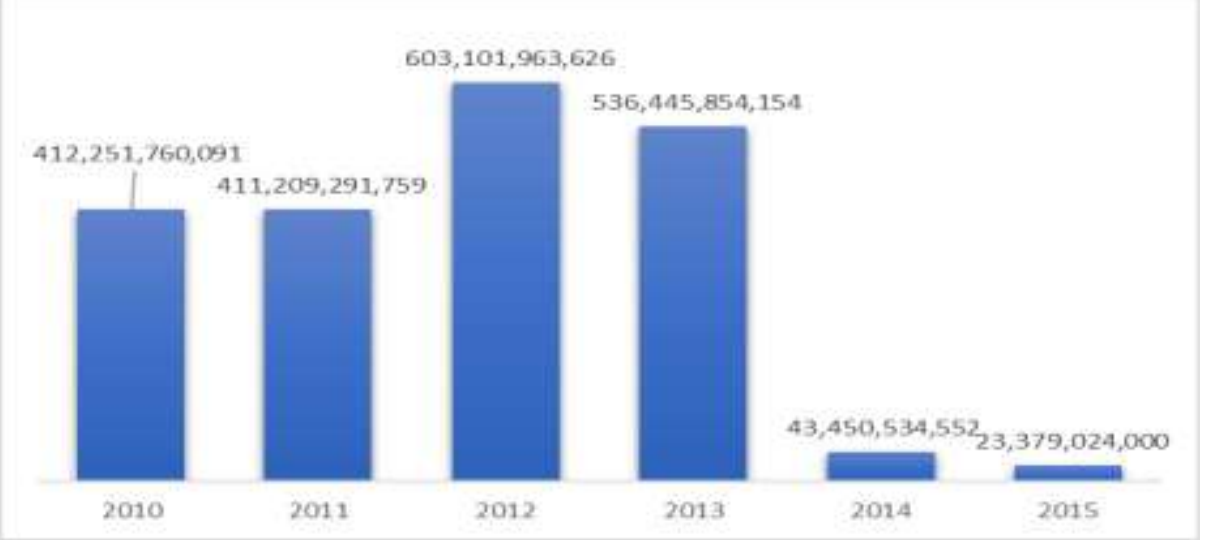

Gambar 1. Sumber Penerimaan Dana Bagi Hasil daerah

Sumber: Bappeda LKPj-AMJ 2010-2015 Bupati Kabupaten Kepulauan Anambas 
Sumber pendapatan asli daerah Kabupaten Kepulauan Anambas untuk sektor pariwisata diperoleh beberapa sumber yaitu pajak hotel, pajak restoran, pajak reklame, dan pajak hiburan. Pendapatan terbesar dari pengguna hotel, restoran, maupun tempat hiburan yang ada di Kabupaten Kepulauan Anambas pada umumnya lebih banyak berasal dari pegawai pemerintah daerah setempat dibandingkan wisatawan luar daerah Kabupaten Kepulauan Anambas, hal ini disebabkan banyak program kegiatan yang ada pada instansi-instansi pemerintah menggunakan penyewaan kamar maupun ruang hotel, memesan makanan di rumah makan serta menggunakan tempat hiburan yang ada. Pengguna hotel, restoran serta tempat hiburan lebih banyak digunakan pegawai pemerintah menyebabkan uang yang beredar atau hasil pajak yang didapat berasal dari anggaran dari anggaran belanja pemerintah daerah Kabupaten Kepulauan Anambas itu sendiri tidak dari uang yang berasal dari luar daerah yang didapat dari tingginya wisatawan yang datang.

Bila pendapatan hotel, restoran, serta tempat hiburan bertambah berasal dari wisatawan luar daerah akan lebih baik untuk peningkatan pajak sektor pariwisata Kabupaten Kepulauan Anambas sehingga akan lebih baik pula pada perolehan peningkatan Pendapatan Asli Daerah Kabupaten Kepulauan Anambas. Untuk menarik wisatawan berkunjung ke wisata Kabupaten Kepulauan Anambas selain obyek wisata yang ada komponen lain juga perlu diperhatikan dan dipersiapkan. Penerimaan Pendapatan Asli Daerah Bidang Pariwisata Kabupaten Kepulauan Anambas disajikan pada Gambar 2.

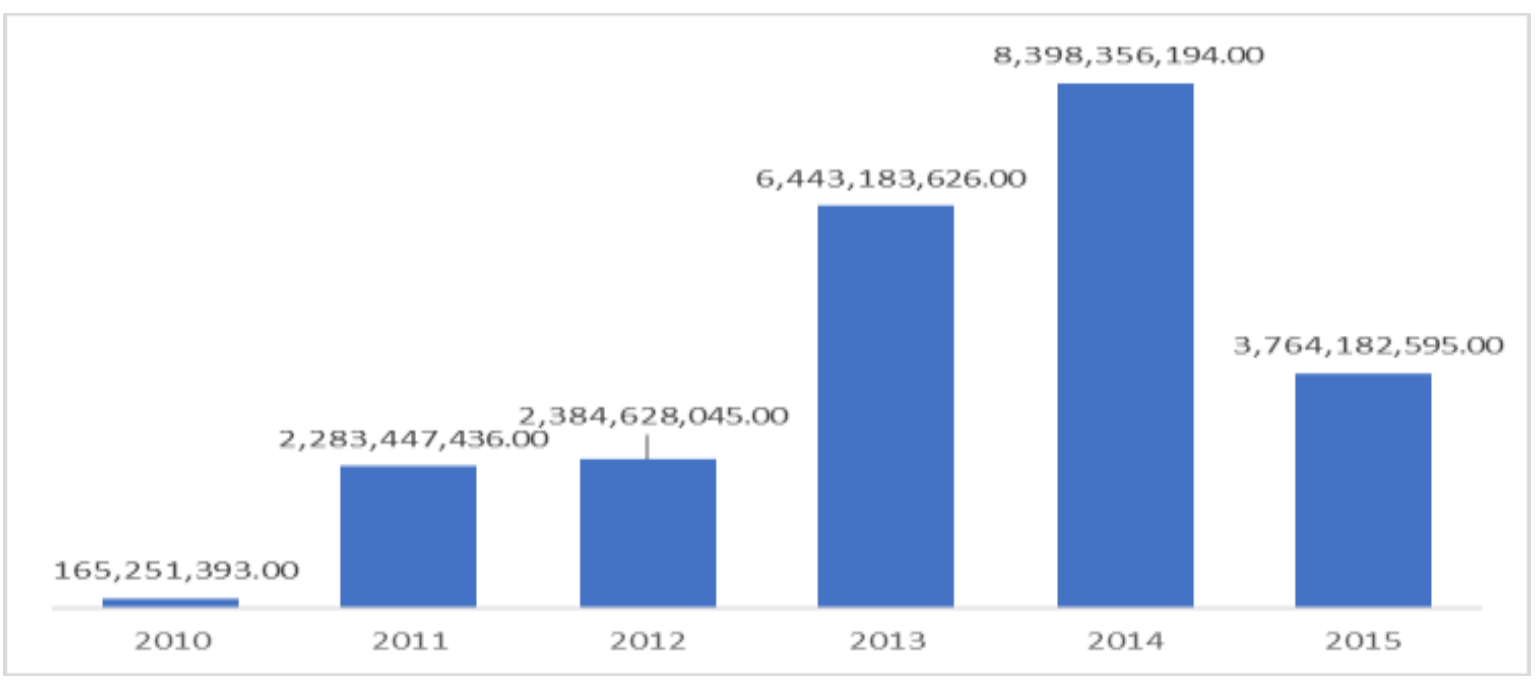

Gambar 2. Penerimaan PAD Bidang Pariwisata Kabupaten Kepulauan Anambas

Sumber: Bappeda LKPj-AMJ 2010-2015 Bupati Kabupaten Kepulauan Anambas

Program kegiatan yang dilaksanakan oleh Dinas Pariwisata Kabupaten Kepulauan Anambas selama ini periode tahun 2010-2015, keikutsertaan masyarakat dalam pengembangan pembangunan pariwisata masih sangat minim. Program kegiatan yang ada banyak mempromosikan obyek wisata yang ada. Pengembangan pembangunan pariwisata berbasis masyarakat untuk peningkatan pendapatan asli daerah memerlukan komponen-komponen yang harus dipersiapkan agar Pariwisata Kabupaten Kepulauan Anambas terwujud yaitu baiknya sarana prasarana di daerah wisata, adanya keterlibatan masyarakat didalamnya akan melengkapi suatu daerah wisata. 
Uraian penyelenggaraan program dan kegiatan dalam urusan Pariwisata selama kurun waktu 2010 - 2015 dapat dilihat dibawah ini. Pembahasan program dan kegiatan berikut adalah program dan kegiatan yang berkaitan langsung dengan penyelenggaraan tugas pokok dan fungsi urusan Pariwisata tidak termasuk program dan kegiatan rutin yang ada pada SKPD yang menangani urusan yang bersangkutan. Rincian program dan kegiatan urusan pariwisata dijelaskan sebagai berikut:

a. Program pengembangan pemasaran pariwisata, program ini didukung 8 (delapan) kegiatan, yaitu:

1. Peningkatan Pemanfaatan Teknologi Informasi Dalam Pemasaran Pariwisata.

2. Pengadaan Media Promosi Pariwisata.

3. Pengembangan jaringan kerjasama promosi pariwisata

4. Festival Padang Melang

5. Pelatihan guide dive

6. Lomba atraksi wisata (Anambas fishing )

7. Fasilitasi kunjungan wisata

8. Pelaksanaan promosi pariwisata nusantara didalam dan diluar negeri

b. Program pengembangan destinasi pariwisata, program ini didukung 13 (tiga belas) kegiatan, yaitu:

1. Peningkatan pembangunan sarana dan prasarana pariwisata

2. Pengembangan Objek pariwisata unggulan pemetaan sport diving

3. DED pulau durai

4. Pelatihan Selam (diving) Executive

5. DED Pariwisata Kabupaten Kepulauan Anambas

6. Pengembangan Jenis dan Paket Wisata unggulan

7. Pemutakhiran data objek dan data sarana dan prasarana pariwisata se Kabupaten

8. Kepulauan Anambas
9. Pengembangan atraksi wisata pantai

10. Penyusunan masterplan kegiatan pariwisata di Kabupaten Kepulauan Anambas

11. Pemantauan dan evaluasi pelaksanaan program pengembangan destinasi

12. Pemasaran Pariwisata

13. Study keterkaitan objek wisata terhadap penguatan daya saing pariwisata

14. Peningkatan olahraga selam (sport diving) menjadi wisata unggulan

15. Penyusunan rencana induk pengembangan pariwisata daerah.

c. Program pengembangan kemitraan, program ini didukung 7 (tujuh) kegiatan, yaitu:

1. Pengembangan Sumber daya manusia dan profesionalisme bidang pariwisata

2. Peningkatan Peran serta masyarakat dalam pengembangan kemitraan pariwisata

3. Pengembangan dan penguatan informasi dan database RIPO

4. Pameran potensi kepariwisataan

5. Workshop dan lomba foto/video

6. Pengembangan dan Penguatan litbang, Kebudayaan dan Pariwisata

7. Monitoring evaluasi dan pelaporan data muktahir kepariwisataan.

Menurut Musenaf (1995) suatu kawasan wisata harus memiliki sarana prasarana, sementara Yoeti (1996) menyebutkan bahwa salah satu obyek penawaran dalam pemasaran pariwisata adalah memiliki infrastruktur penunjang wisata. Sarana dan prasarana pendukung pariwisata Kabupaten Kepulauan Anambas yang ada masih banyak kurang memadai, wilayah yang dapat memenuhi kebutuhan para wisatawan dengan fasilitas yang ada belum diketahui, masih sedikit keterlibatan masyarakat, dan pengembangan pembangunan pariwisata 
yang belum mengikutsertakan para stakeholders harus dapat untuk di libatkan. Berdasarkan latar belakang dan perumusan masalah, tujuan dari penelitian ini adalah:

1. Menganalisis sarana prasarana pendukung pariwisata untuk dapat mempersiapkan pembangunan pariwisata Kabupaten Kepulauan Anambas, dan penentuan wilayah yang dapat memenuhi kebutuhan para wisatawan dengan fasilitas yang telah ada.

2. Menganalisis pemberdayaan masyarakat dalam pengembangan pembangunan pariwisata berbasis masyarakat.

3. Merumuskan strategi pengembangan pembangunan pariwisata berbasis masyarakat untuk peningkatan Pendapatan Asli Daerah Kabupaten Kepulauan Anambas yang melibatkan lembaga usaha milik pemerintah daerah.

\section{METODOLOGI}

Metode analisis yang digunakan dalam penelitian ini adalah

1. Analisis Kruskallwalis

Analisis sarana prasarana pendukung dalam pengembangan pembangunan pariwisata Kabupaten Kepulauan Anambas di analisis dengan menggunakan Kruskallwalis dimana sarana prasarana yang harus ada dalam mengembangkan daerah wisata yaitu Fasilitas pendukung transportasi, Jaringan jalan, Transportasi darat, Transportasi laut, Transportasi udara, Jaringan listrik, Penyediaan air bersih, Telekomunikasi, Fasilitas penginapan/ hotel, Tempat makan/restoran, Fasilitas pembelanjaan, Sarana rekreasi wisata bahari, Fasilitas pelayanan keuangan, Fasilitas pelayanan kesehatan, Sistem 34 pengolahan limbah dan sanitasi prasarana, Drainase, dan Persampahan.

Menganalisis wujud partisipasi masyarakat dalam Pariwisata Berbasis Masyarakat Kabupaten Kepulauan Anambas juga mengunakan analisis Kruskallwalis yang dapat diikutsertakan, merupakan aktifitas yang sering dilakukan masyarakat setempat berkaitan dengan kepariwisataan yaitu pemandu wisata bawah, penyediaan home stay milik masyarakat setempat, penyewaan kapal motor laut milik masyarakat, menampilkan budaya khas daerah, menjual makanan-makanan khas daerah, menjual "kerajinan-kerajinan" hasil karya masyarakat, budidaya ikan milik masyarakat, dan budidaya ikan laut lepas.

2. Analisis Skalogram

Wilayah yang dapat memenuhi kebutuhan parawisatawan suatu daerah wisata merupakan penentuan wilayah yang mana daerah tersebut telah ada tersedianya fasilitas-fasilitas. Penentuan wilayah menggunakan analisis Skalogram, sehingga dapat menentukan keberadaan posisi hierarki I, II, dan III. Wilayah hierari I memiliki fasilitas lebih banyak dibandingkan wilayah hierarki II, dan wilayah hierarki II memiliki fasilitas lebih banyak dibandingkan wilayah hierarki I.

2. Analisis SWOT (Strength, Weakness, Opportunity, Treat) untuk merumuskan strategi, dilanjutkan dengan penentuan prioritas startegi yang dihasilkan menggunakan perhitungan analisis QSPM (Quantitative Strategi Planning Matrix).

\section{HASIL DAN PEMBAHASAN}

Sarana Prasarana Pendukung Pariwisata dalam Pengembangan Pembangunan Pariwisata Kabupaten Kepulauan Anambas 
Berdasarkan analisa Kruskallwalis diperoleh nilai p-value sebesar 0.0001 lebih kecil dari alpha (0.05) menunjukan terdapat perbedaan yang signifikan di antara jenis sarana prasarana pendukung pariwisata Kabupaten Kepulauan Anambas. Sarana prasarana pendukung yang di siapkan dan ditingkatkan dalam pengembangan pembangunan pariwisata Kabupaten Kepulauan Anambas adalah Transportasi laut dan Sarana rekreasi wisata bahari dengan nilai paling tinggi sebesar 4.93. Transportasi laut merupakan alat transportasi yang mengantarkan penumpang dan barang dari daerah luar ke Kabupaten Kepulauan Anambas.

Transportasi laut yang beroperasi yaitu Kapal ferry dan kapal miliki PT. Pelni. Kapal ferry yang beroperasi hanya ada satu dengan dua hari satu kali mengunjungi daerah Kabupaten Kepulauan Anambas dengan lama perjalanan delapan sampai sepuluh jam, sedangkan untuk kapal Pelni dua minggu satu kali mengunjungi Kabupaten Kepulauan Anambas. Dengan sarana prasarana transportasi yang kurang, aksesibiltas yang kurang lancar membuat wisatawan berpikir untuk mengunjungi wisata yang ada di Kabupaten Kepulauan Anambas. Begitu pula dengan sarana rekreasi wisata bahari yang belum ada tersedia padahal obyek wisata yang ada di daerah Kabupaten Kepulauan Anambas selain pulau dengan pantai yang indah daerah ini juga memiliki obyek wisata bawah laut yang menarik yang dapat diandalkan, namun belum tersedia sarana seperti kelengkapan peralatan snorkeling atau peralatan lainnya untuk parawisatawan. Peralatan yang ada selama ini masih milik Dinas Pariwisata Kabupaten Kepulauan Anambas dan beberapa milik masyarakat, yang tidak untuk dipinjamkan atau disewakan ke semua parawisatawan yang datang, hanya orang yang mengenal dan orang tertentu saja yang dapat menggunakannya. Dengan tidak banyak tersedianya sarana rekreasi membuat wisatawan kurang berminat untuk mengunjungi daerah wisata bahari yang ada.

Sarana prasarana pendukung yang harus di siapkan dan ditingkatkan dalam pengembangan pembangunan pariwisata Kabupaten Kepulauan Anambas dengan nilai paling tinggi transportasi laut dan sarana rekreasi wisata bahari terletak pada kategori golongan "F". Untuk sarana prasarana tempat makan/restoran, fasilitas pembelanjaan, penyediaan air bersih, telekomunikasi, persampahan, jaringan listrik, transportasi udara, fasilitas penginapan/hotel termasuk terletak pada kategori golongan "EF" artinya antara sarana prasarana satu dengan sarana prasarana lainya memiliki kategori yang sama golongan "EF".

Sarana prasarana yang memiliki kategori yang sama-sama golongan "EF" tidak harus mendahulukan pembangunan sarana prasarana yang memiliki nilai lebih tinggi, ini disebabkan golongan sarana prasarana memiliki tingkat untuk dilaksanakan sama-sama penting karna tergolong kategori golongan yang sama. Sarana prasarana pendukung pariwisata Kabupaten Kepulauan Anambas dengan kategori golongan "F" memiliki nilai yang lebih tinggi dari pada sarana prasarana pendukung dengan kategori golongan "EF" artinya Sarana prasarana pendukung pariwisata Kabupaten Kepulauan Anambas dengan kategori golongan "F" lebih harus didahulukan dibanding sarana prasarana pendukung dengan kategori golongan "EF", namun kategori golongan "EF" harus tetap perlu ditingkatkan agar saling melengkapi dalam mendukung pengembangan pembangunan pariwisata Kabupaten Kepulauan Anambas.

Begitu pula dengan kategori nilai "DE, CD, BC, B, A" memiliki nilai yang berbeda antara kategori yang satu dengan yang lainnya, dengan nilai golongan yang lebih tinggi yang harus didahulukan untuk dilaksanakan dan nilai yang rendah 
untuk tidak didahulukan. Sarana prasarana pendukung pengembangan pembangunan pariwisata Kabupaten Kepulaunan Anambas dapat dilihat pada Tabel 1.

Sistem pengolahan limbah dan sanitasi prasarana mimiliki nilai yang paling rendah sebesar 1.75 dikarenakan fasilitas ini cukup tersedia dibandingkan fasilitas pendukung pariwisata lainnya yang masih sangat perlu terlebih dahulu untuk disiapkan dan dikembangkan.

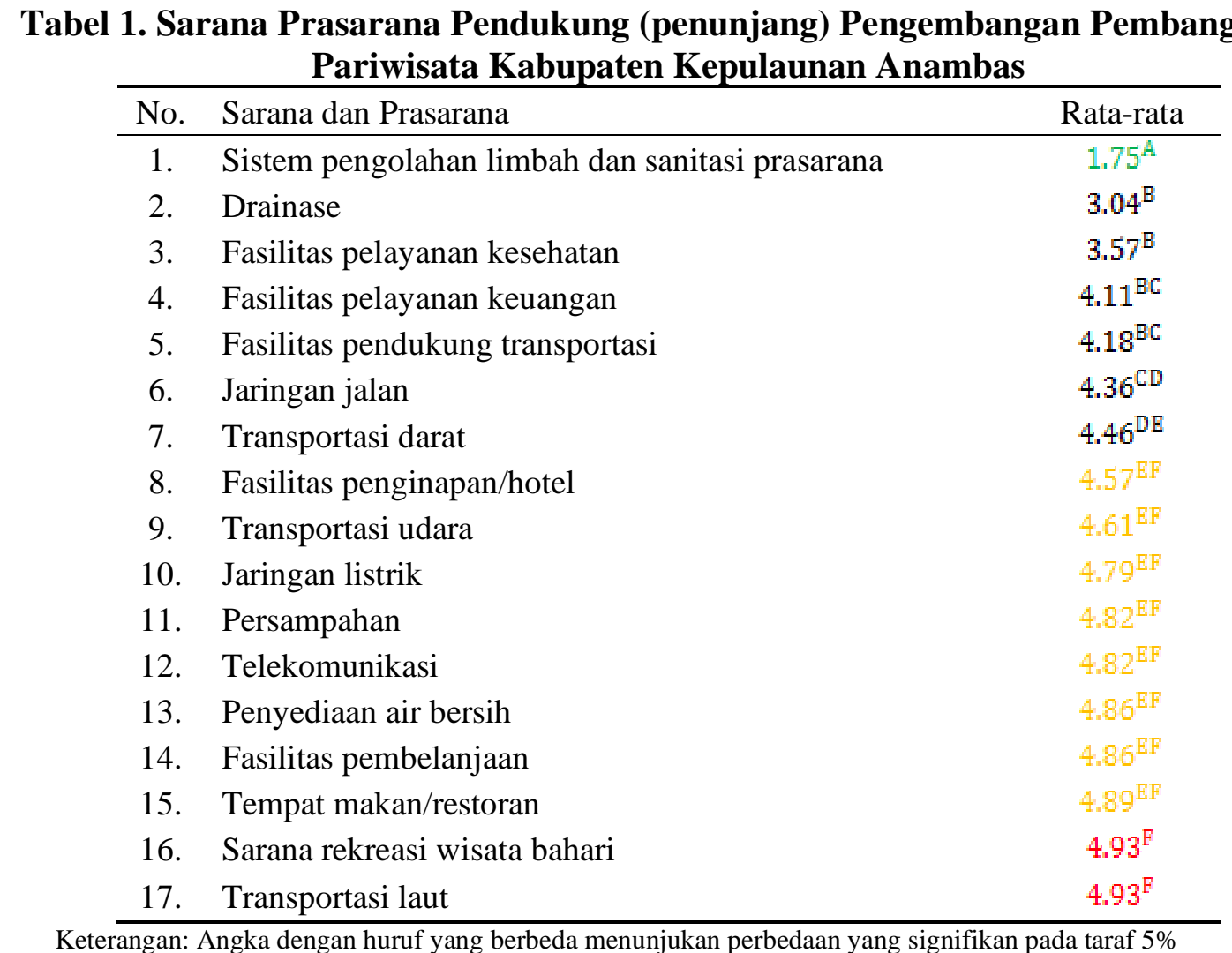

Wilayah yang Memenuhi Kebutuhan Wisatawan dalam Pengembangan Pembangunan Pariwisata Kabupaten Kepulauan Anambas

Berdasarkan hasil analisis Skalogram fasilitas yang ada di ke 7 (tujuh) Kecamatan Kabupaten Kepulauan Anambas menunjukan bahwa hanya satu kecamatan yang termasuk ke dalam hierarki I yaitu Kecamatan Siantan dengan jumlah 59.54. Kecamatan Siantan merupakan kecamatan paling lama, sebelum Kabupaten Kepulauan Anambas terbentuk Kecamatan Siantan masih bergabung dengan Kabupaten Natuna oleh karenanya Kecamatan Siantan telah banyak fasilitas dibangun dan tersedia. Kecamatan Siantan memiliki paling banyak jumlah penduduk, Kecamatan Siantan merupakan ibukota Kabupaten Kepulauan Anambas sehingga kelengkapan fasilitas sangat diperlukan dan lebih lengkap dari KecamatanKecamatan yang ada.

$$
\text { Pada hierarki II terdapat } 4
$$

Kecamatan, yaitu Kecamatan Jemaja sebesar 36.20, Jemaja Timur sebesar 30.99, Siantan Tengah sebesar 21.68, dan Siantan Selatan sebesar 18.26 karena fasilitas yang dimiliki lebih sedikit dibandingkan dengan Kecamatan Siantan yang dikategorikan sebagai desa hierarki I. Kecamatan Jemaja menempati rangking 2 (dua) yang berada di hierarki II hal ini disebabkan karena Kecamatan Jemaja juga sudah banyak terdapat 
fasilitas. Luas wilayah, banyaknya penduduk dan jarak dari ibu kota Kabupaten tidak selalu menentukan banyaknya fasilitas yang dibangun selama ini oleh pemerintah daerah, ini terbukti Kecamantan Jemaja yang memiliki luas wilayah yang kecil, jumlah penduduk yang tidak terlalu banyak dan jarak yang jauh dari ibukota Kabupaten, memiliki fasilitas masyarakat yang lebih lengkap dibanding dengan 5 (lima) Kecamatan lainnya dan Kecamatan Jemaja memungkinkan untuk pengembangan pembangunan pariwisata sebagai wilayah yang dapat memenuhi kebutuhan wisatawan pada saat berkunjung setelah Kecamatan Siantan, yang dikarenakan telah banyaknya fasilitas-fasilitas yang telah di bangun yang ada diwilayah tersebut.

Kecamatan Siantan Timur dengan

nilai sebesar 15.54 dan Kecamatan
Palmatak dengan nilai sebesar 13.30 terletak di hierarki III, hierarki yang lebih rendah dan memiliki fasilitas sarana dan prasarana lebih sedikit dibandingkan hierarki II dan Kecamatan Palmatak merupakan Kecamatan yang memiliki jumlah fasilitas sarana dan prasarana paling sedikit dari ke 6 (enam) Kecamatan lainnya.

Untuk dapat meningkatkan pengembangan pembangunan pariwisata di daerah wisata salah satunya yaitu terletak ketersediaan fasilitas, bila fasilitas yang ada di suatu wilayah tidak dapat tersedia maka pemenuhan dalam kebutuhan yang dibutuhkan wisatawan tidak dapat terpenuhi, hal ini akan mengurangi minat wisatawan yang akan berkunjung. Hasil perhitungan wilayah Kecamatan berdasarkan banyaknya fasilitas di Kabupaten Kepulauan Anambas dapat dilihat pada Tabel 2.

Tabel 2. Wilayah Kecamatan Berdasarkan Banyaknya Fasilitas Kabupaten Kepulauan Anambas

\begin{tabular}{lccl}
\hline \multicolumn{1}{c}{ Kecamatan } & Jumlah total & Ranking & Hierarki \\
\hline Siantan & 59.54 & 1 & Hierarki I \\
Palmatak & 13.30 & 7 & Hierarki III \\
Siantan Timur & 15.54 & 6 & Hierarki III \\
Siantan Selatan & 18.26 & 5 & Hierarki II \\
Jemaja Timur & 30.99 & 3 & Hierarki II \\
Jemaja & 36.20 & 2 & Hierarki II \\
Siantan Tengah & 21.68 & 4 & Hierarki II \\
\hline
\end{tabular}

Sumber: Data primer yang di olah

\section{Wujud Pemberdayaan Masyarakat dalam Pengembangan Pembangunan Pariwisata Berbasis Masyarakat Kabupaten Kepulauan Anambas}

Wujud pemberdayaan masyarakat dalam pariwisata berbasis masyarakat Kabupaten Kepulauan Anambas berdasarkan analisis Kruskallwalis diperoleh nilai $\mathrm{p}$-value sebesar 0.0001 lebih kecil dari alpha (0.05) menunjukan terdapat perbedaan yang signifikan di antara jenis Wujud Pemberdayaan Masyarakat dalam Pengembangan Pembangunan Pariwisata Berbasis Masyarakat. Kategori golongan "B" Wujud Pemberdayaan Masyarakat yaitu
(1) pembudidayaan ikan laut lepas, pembudidayaan ikan keramba apung dan dapat menjadi salah satu destinasi obyek wisata Kabupaten Kepulauan Anambas, wujud pemberdayaan ini merupakan aktifitas yang sering dilakukan masyarakat dan merupakan mayoritas pekerjaan masyarakat Kabupaten Kepulauan Anambas, (2) Hasil karya masyarakat kerajinan khas daerah (3) Makanan khas daerah, sama-sama memiliki nilai paling tinggi sebesar 4.79, (4) Masyarakat pemuda pemudi dapat menampilkan budaya khas daerah memiliki nilai sebesar 4.64 dan (5) Penyewaan kapal motor laut milik 
masyarakat memiliki nilai sebesar 4.54 . Bentuk pemberdayaan yang dibuat merupakan bentuk pemberdayaan masyarakat yang sering dilakukan dalam keseharian masyarakat Kabupaten Kepulauan Anambas yang harus lebih diikutsertakan, dan harus lebih ditingkatkan dengan diberikan pengarahan, bimbingan atau pelatihan agar bentuk pemberdayaan masyarakat kategogi golongan "B" menjadi lebih baik.

Kategori golongan "A" kategori golongan lebih kecil nilainya dari pada kategori golongan "B" artinya kategori golongan " $\mathrm{B}$ " merupakan bentuk pemberdayaan masyarakat lebih banyak yang menyetujui untuk di ikutsertakan dalam melengkapi pengembangan pembangunan pariwisata berbasis masyarakat Kabupaten Kepulauan Anambas. Wujud pemberdayaan masyarakat di kategori golongan "A" yaitu (1) Penyewaan penginapan (home stay) milik masyarakat dengan nilai 3.93 dan (2) Masyarakat menjadi pemandu wisata bawah laut dengan nilai 3.36.

Masyarakat setempat menjadi pemandu wisata bawah laut untuk wisatawan yang berkunjung merupakan bentuk pemberdayaan masyarakat dengan nilai yang paling rendah yaitu sebesar 3.36, ini dikarenakan dalam memandu wisatawan di bawah laut harus memiliki keahlian khusus dan profesional. Pemandu tidak hanya bisa berenang dan menyelam saja dan mengetahui tempattempat bawah laut yang indah namun pemandu harus mengerti prosedur pada saat berada dibawah laut sehingga wisatawan akan aman selama dalam melakukan penyelaman dibawah laut, dalam hal ini masyarakat setempat tidak mengusainya. Hasil perhitungan wujud pariwisata berbasis masyarakat Kabupaten Kepulauan Anambas dapat dilihat pada Tabel 3 .

\section{Tabel 3. Aktifitas Masyarakat Dalam Mewujudkan Pariwisata Berbasis Masyarakat} Kabupaten Kepulauan Anambas

\begin{tabular}{|c|c|c|}
\hline No. & $\begin{array}{c}\text { Bentuk Keikutsertaan Masyarakat dalam Pengembangan Pembangunan } \\
\text { Pariwisata Berbasis Masyarakat }\end{array}$ & Rata-rata \\
\hline 1. & $\begin{array}{l}\text { Masyarakat menjadi pemandu wisata bawah laut bagi wisatawan yang } \\
\text { berkunjung. }\end{array}$ & $3.36^{A}$ \\
\hline 2. & $\begin{array}{l}\text { Masyarakat dapat menerima wisatawan yang ingin menginap (home stay) } \\
\text { milik masyarakat setempat dengan suasana kekhasan daerah Kepulauan } \\
\text { Anambas dengan keunikannya yang kemudian masyarakat mendapatkan } \\
\text { keuntungan dari itu. }\end{array}$ & $3.93^{\mathrm{A}}$ \\
\hline 3. & $\begin{array}{l}\text { Masyarakat yang memiliki kapal motor laut dapat membawa wisatawan yang } \\
\text { ingin berkunjung ke pulau atau ke obyek wisata. }\end{array}$ & $4.54^{\mathbb{B}}$ \\
\hline 4. & $\begin{array}{l}\text { Masyarakat, pemuda pemudi dapat menampilkan budaya khas daerah } \\
\text { (budaya/kebiasaan yang ada yang baik dan menarik) ke wisatawan yang } \\
\text { berkunjung. }\end{array}$ & $4.64^{\mathbb{B}}$ \\
\hline 5. & $\begin{array}{l}\text { Masyarakat dapat menjual makanan-makanan khas daerah dari hasil buatan } \\
\text { masyarakat setempat. }\end{array}$ & $4.79^{B}$ \\
\hline 6. & $\begin{array}{l}\text { Masyarakat dapat menjual "kerajinan-kerajinan" yang dibuat masyarakat } \\
\text { setempat. }\end{array}$ & $4.79^{\mathbb{B}}$ \\
\hline 7. & $\begin{array}{l}\text { Masyarakat dapat membudidayakan ikan yang masyarakat miliki dan ini } \\
\text { dapat dikunjungi wisatawan dan masyarakat setempat dapat menjual ke para } \\
\text { wisatawan yang ingin membeli. }\end{array}$ & $4.79^{\mathbb{B}}$ \\
\hline 8. & $\begin{array}{l}\text { Masyarakat dapat membudidayakan ikan-ikan laut lepas dengan cara } \\
\text { membuat sarang ikan seperti rumpon, yang tentunya tidak merusak karang, } \\
\text { dan tidak membuang sampah ditengah laut agar ikan laut lepas dapat tetap } \\
\text { berkembangbiak dengan jumlah yang banyak. (Bantuan Pemerintah) }\end{array}$ & $4.79^{18}$ \\
\hline
\end{tabular}

Keterangan: Angka dengan huruf yang berbeda menunjukan perbedaan yang signifikan pada taraf $5 \%$ 
Strategi pengembangan pembangunan pariwisata berbasis masyarakat untuk meningkatkan Pendapatan Asli Daerah Kabupaten Kepulauan Anambas menggunakan matriks SWOT (Strength, Weakness, Opportunity, Treat). Strategi $\mathrm{S}-\mathrm{O}$ atau penggabungan antara Kekuatan (Strengths) dan Peluang (Opportunities) menghasilkan 2 (dua) strategi yaitu pertama pemberlakuan kebijakan investasi yang kondusif, kedua peningkatan peran dan pengembangan kerjasama kepariwisataan antar pemerintah, masyarakat dan swasta. Strategi W-O (WeaknessesOpportunities) yaitu pertama peningkatan sarana prasarana umum dan sarana prasarana kepariwisataan Kabupaten Kepulauan Anambas, kedua peningkatkan keterlibatan masyarakat dalam pengembangan kepariwisataan Kabupaten Kepulauan Anambas, ketiga meningkatkan peran lembaga usaha milik pemerintah, keempat peningkatan penciptaan peluang restribusi/pajak (memahami/dapat membaca peluang restribusi/pajak) dan peningkatan pemungutan restribusi/pajak yang sudah ada. Strategi S-T (Strengths-Treats) yaitu pertama peningkatan pelestarian lingkungan, kedua pembinaan untuk masyarakat dampak negatif dari pengembangan kepariwisataan. Strategi W-T (Weaknesses- Treats) yaitu peningkatan keamanan dan peraturan keamanan daerah. Strategi pengembangan Pembangunan Pariwisata Kabupaten Kepulauan Anambas dapat dilihat pada Tabel 4.
Strategi pengembangan pembangunan pariwisata berbasis masyarakat untuk meningkatkan Pendapatan Asli Daerah Kabupaten Kepulauan Anambas menggunakan perhitungan matriks SWOT menghasilkan sembilan strategi, namun memerlukan pemilihan strategi yang harus diprioritaskan. Penentukan strategi yang terlebih dahulu harus dilaksanakan, menggunakan analisis Quantitative Strategi Planning Matrix (QSPM) yang hasilnya adalah: (1) Peningkatan sarana prasarana umum dan sarana prasarana bidang pariwisata Kabupaten Kepulauan Anambas dengan nilai 9.999, (2) Meningkatkan keterlibatan masyarakat dalam pengembangan pariwisata Kabupaten Kepulauan Anambas dengan nilai 9.927.579, (3) Meningkatkan peran lembaga usaha milik pemerintah dengan nilai 9.427.629, (4) Peningkatan penciptaan peluang restribusi/pajak (memahami/dapat membaca peluang restribusi/pajak) dan peningkatan pemungutan restibusi/pajak yang sudah ada dengan nilai 8.499.15, Peningkatan pelestarian lingkungan dengan nilai 8.356.307, (6) Peningkatan keamanan daerah dan peraturan keamanan daerah dengan nilai 8.213.464, (7) Peningkatan peran dan pengembangan kerjasama kepariwisataan antar pemerintah, masyarakat dan swasta dengan nilai 7.784.936, (8) Pemberlakuan kebijakan investasi yang kondusif dengan nilai 7.570.671, dan (9) Pembinaan untuk masyarakat, dampak negatif dari pengembangan kepariwisataan dengan nilai 6.785.036. 
Tabel 4. Strategi Pengembangan Pembangunan Pariwisata Berbasis Masyarakat untuk Peningkatan Pendapatan Asli Daerah Kabupaten Kepulauan Anambas

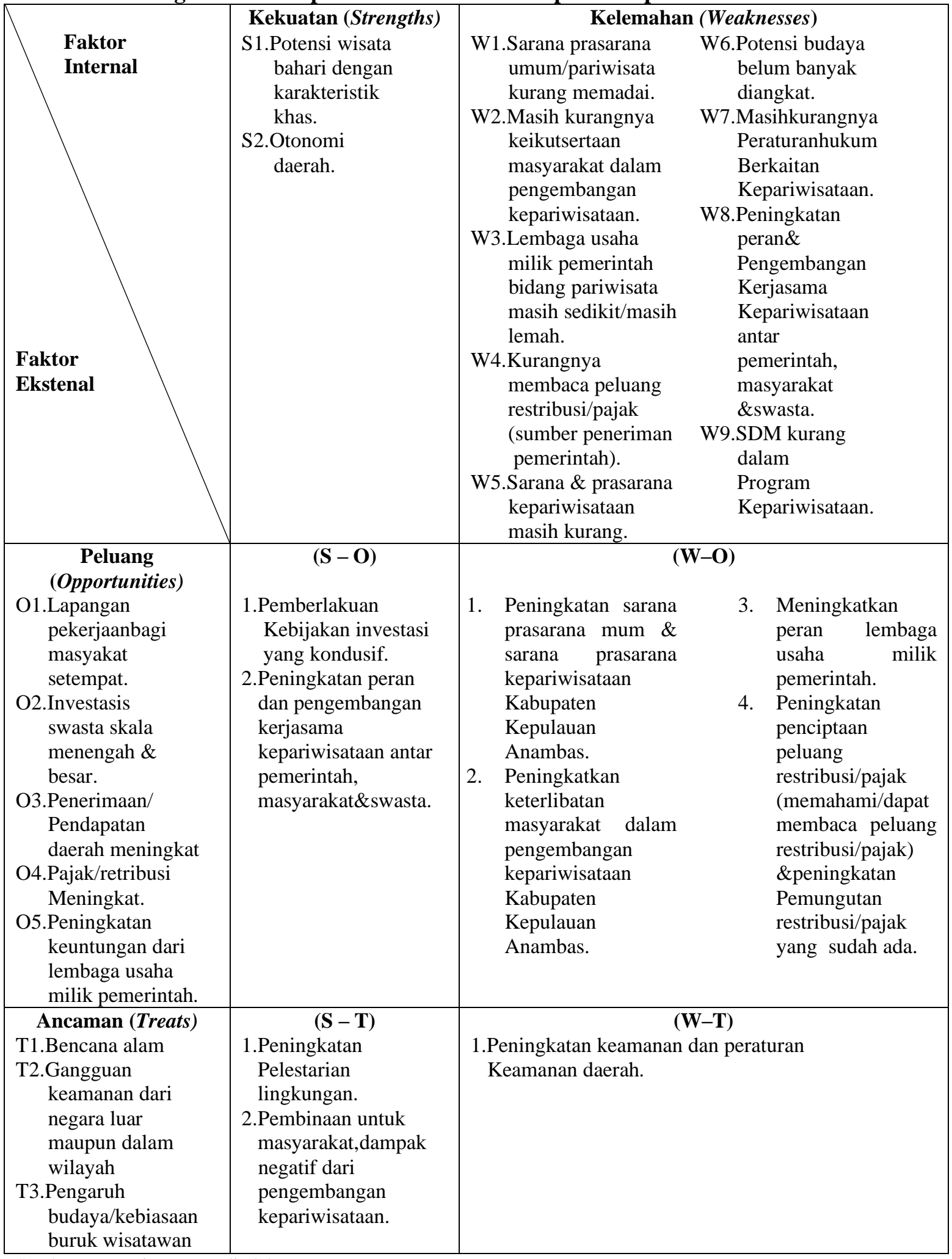

Sumber: Data primer yang di olah

Keseluruhan strategi yang dihasilkan dari analisis QSPM dapat diimplementasikan secara bersama dan saling mendukung antara strategi yang satu dengan strategi lainnya, karena strategi yang dihasilkan melibatkan berbagai pihak stakeholders yang harus saling mendukung. Namun dalam hal ini 
harus tetap menentukan strategi yang

harus didahulukan untuk dilaksanakan.
Prioritas Strategi Pariwisata dapat dilihat pada Tabel 5.

Tabel 5. Prioritas Strategi Pariwisata Berbasis Masyarakat untuk Peningkatan Pendapatan Asli Daerah Kabupaten Kepulauan Anambas dilanjutkan Menggunakan Analisis Quantitative Strategi Planning Matrix (QSPM).

\begin{tabular}{clcc}
\hline No. & \multicolumn{1}{c}{ Strategi } & Skor & Ranking \\
\hline 1. & $\begin{array}{l}\text { Peningkatan peran dan pengembangan kerjasama } \\
\text { kepariwisataan antar pemerintah, masyarakat dan swasta. }\end{array}$ & 7.784 .936 & 7 \\
2. $\begin{array}{l}\text { Peningkatan sarana prasarana umum dan sarana prasarana } \\
\text { bidang pariwisata Kabupaten Kepulauan Anambas. }\end{array}$ & 9.999 & 1 \\
3. $\begin{array}{l}\text { Meningkatkan keterlibatan masyarakat dalam pengembangan } \\
\text { pariwisata Kabupaten Kepulauan Anambas. }\end{array}$ & 9.927 .579 & 2 \\
4. Meningkatkan peran lembaga usaha milik pemerintah. & 9.427 .629 & 3 \\
5. Pemberlakuan kebijakan investasi yang kondusif. & 7.570 .671 & 8 \\
6. Peningkatan penciptaan peluang restribusi/pajak (memahami/ & 8.499 .15 & 4 \\
$\begin{array}{l}\text { dapat membaca peluang restribusi/pajak) dan peningkatan } \\
\text { pemungutan restibusi/pajak yang sudah ada. }\end{array}$ & & \\
$\begin{array}{l}\text { Peningkatan keamanan daerah dan peraturan keamanan } \\
\text { 8eningkatan pelestarian lingkungan. }\end{array}$ & 8.213 .464 & 6 \\
9. Pembinaan untuk masyarakat, dampak negatif dari & 6.785 .036 & 9 \\
\hline
\end{tabular}

Sumber: Data primer yang di olah

Meningkatkan sarana prasarana umum maupun sarana prasarana kepariwisataan, tersedianya fasilitas di Kecamatan Siantan yang dapat memenuhi kebutuhan parawistawan, adanya keikutsertaan masyarakat dalam pengembangan pembangunan pariwisata melengkapi pariwisata Kabupaten Kepulauan Anambas, sehingga dengan tersedianya komponen-komponen tersebut akan memudahkan, menarik dan meningkatkan wisatawan untuk berkunjung ke wisata Kabupaten Kepulauan Anambas. Meningkatnya wisatawan, akan berpengaruh terhadap peningkatan permintaan seperti diantaranya hotel/penginapan, restoran/rumah makan, dan tempat hiburan dengan demikian peran lembaga usaha milik pemerintah daerah Kabupaten Kepulauan Anambas untuk dapat menciptakan usaha-usaha kepariwisataan yang menarik membuat wisatawan berkeinginan lebih lama tinggal dan lebih banyak mengeluarkan uangnya, sehingga lembaga usaha milik pemerintah daerah akan mendapatkan keuntungan dari usaha-usaha yang dibangun menambah sumber penerimaan daerah Kabupaten Kepulauan Anambas melalui Pendapatan Asli daerah.

Lengkapnya sarana prasarana, tersedianya fasilitas di Kecamatan (wilayah) yang dapat memenuhi kebutuhan parawisatawan, adanya keikutsertaan masyarakat dengan sendirinya akan menarik para pihak swasta membangun usaha-usaha yang dibutuhkan wisatawan seperti tumbuhnya industri hotel, restoran, tempat hiburan, transportasi dan lainya. Tumbuhnya usaha-usaha kepariwisataan milik pihak swasta, memberi peluang kepada pemerintah daerah Kabupaten Kepulauan Anambas untuk dapat menarik pajak dan restribusi daerah dari usaha-usaha milik pihak swasta yang kemudian juga akan meningkatkan Pendapatan Asli Daerah Kabupaten Kepulauan Anambas dan berimbas terhadap meningkatnya APBD (Anggaran Pendapatan Belanja Daerah) yang dapat menjadikan Kabupaten Kepulauan Anambas daerah yang mandiri. 


\section{SIMPULAN}

Berdasarkan hasil dan pembahasan yang telah disajikan sebelumnya, dapat disimpulkan beberapa hal sebagai berikut:

1. Peningkatan sarana prasarana umum maupun sarana prasarana bidang pariwisata yaitu transportasi laut dan sarana prasarana rekreasi wisata bahari, adanya wilayah yang dapat memenuhi kebutuhan wisatawan yaitu terdapat di Kecamatan Siantan memberikan kenyamanan bagi wisatawan dalam memenuhi apa yang dibutuhkan para wisatawan pada saat berkunjung ke daerah wisata Kabupaten Kepulauan Anambas.

2. Keikutsertaan masyarakat berupa pengembangan pembudidayaan ikan yang mana memanfaatkan aktifitas yang sering dilakukan masyarakat. Mengembangkan kerajinankerajinan, makanan khas daerah, memberikan kelengkapan destinasi daerah wisata Kabupaten Kepulauan Anambas, serta dapat memberikan peningkatan perekonomian dan kesejahteran masyarakat setempat.

3. Perencanaan yang terarah, melibatkan berbagai stakeholders, dan tidak hanya memberatkan kepada Dinas pariwisata semata dalam pengembangan pembangunan pariwisata. Memiliki tenaga profesional dalam mengelola lembaga usaha milik pemerintah daerah ikut berpengaruh terhadap lancarnya peningkatan pada Pendapatan Asli Daerah Kabupaten Kepulauan Anambas.

\section{SARAN}

Beberapa hal yang dapat disampaikan sebagai saran antara lain:

Daerah wisata tidak mendapatkan kunjungan wisatawan yang tinggi bila 42 daerah wisata belum mempersiapkan apa yang dibutuhkan wisatawan. Wisatawan tidak hanya melihat obyek wisata yang indah namun wisatawan memerlukan berbagai kebutuhan pada saat berkunjung ke daerah wisata. Promosi yang berlebihan tanpa menyiapkan apa yang dibutuhkan para wisatawan juga tidak dapat memberikan kunjungan wisatawan yang tinggi di daerah wisata, oleh karenanya pemerintah daerah serta stakeholders terkait untuk dapat saling bekerjasama dan melengkapi apa yang harus dipersiapkan dan apa yang harus diwujudkan dalam pembangunan pariwisata Kabupaten Kepulauan Anambas.

\section{DAFTAR PUSTAKA}

BAPPEDA Kabupaten Kepulauan Anambas. LKPj-AMJ 2010-2015 Bupati Kepulauan Anambas.

Badan Pusat Statistik Kabupaten Kepulauan Anambas. Anambas Dalam Angka 2015.

Bratakusumah, Supriady, Deddy dan Solihin, Dadang. 2000. Otonomi Penyelenggaraan Pemerintah Daerah. Jakarta. Gramedia Pustaka Utama.

Fandeli. 2000. Kebijakan Pengembangan Ekowisata: Pengembangan Ekowisata Dengan Paradigma Baru Pengelolaan Areal Konservasi. Yogyakarta (ID): Fakultas Kehutanan Universitas Gajah Mada.

Hadi SP. 2005. Aspek Sosial AMDAL: Sejarah Teori dan Metode. Yogyakarta (ID): Universitas Gajah Mada.

Hartono, Doni. 2006. Pengaruh Pengembangan Sarana Pokok Pariwisata Terhadap Pendapatan Asli Daerah di Kabupaten Pasuruan. Universitas Muhammadiyah

Malang.http://ejournal.umm.ac.id/ index.php/jeb/ (Diakses 9 Februari 2016).

Hofer dan Schandel. 1981. Pertahanan Keamanan dan Strategi Nasional. Jakarta. Yayasan Proklamasi 
Centre For Strategi and Internasioanal Studies.

Kementerian Dalam Negeri, 2013. Dana Perimbangan, Sumber Pendapatan Daerah Terbesar. http://www.keuda.kemendagri.go. id/artikel/detail(Diakses 9 Februari 2016).

Kodhayat. 1996. Sejarah Pariwisata Dan Perkembangannya Di Indonesia. Jakarta. Penerbit Grasindo.

Koswara, Ina, Herlina. 1998. Konsentrasi Spesial dan Sektoral Fasilitas Penunjang Kepariwisataan (Pariwisata Indonesia Menuju Keputusan Yang Lebih Baik). Bandung. ITB.

Koentraninggrat. 1997. Metode Penelitian Masyarakat. Jakarta. PT. Gramedia.

Kusmuljono. 2009. Menciptakan Kesempatan Rakyat Berusaha, Sebuah Konsep Baru tentang Hybrid Microfinancing. Bogor. IPB Press.

Latupapua Y. 2011. Persepsi Masyarakat Terhadap Potensi Obyek Daya Tarik Wisata Pantai di Kecamatan Kei Kecil Kabupaten Maluku Tenggara Universitas Patimura. Jurnal Agroforestry.

Lynnarsatia, Bramantio. 2000. Analisis Perkembangan Industri Pariwisata dan Pengaruhnya Terhadap Pendapatan Asli Daerah di Kota Surakarta Tahun
1990-2000. Universitas Sebelas

Maret. http://www.uns.ac.id/ digilib (Diakses 9 Feberuari 2016).

Magriasti, Lince. 2011. Arti Penting Partisipasi Masyarakat Dalam Kebijakan Publik di Daerah: Analisis dengan Teori Sistem David Easton. Universitas Negeri Padang. http://www.fisip-untirta. ac.id/eJLAN/ (Diakses 9 Februari 2016).

Musenaf. 1995. Manajemen Usaha Pariwisata Di Indonesia. Jakarta. PT. Toko Gunung Agung.

Siahaan, Marihot. 2005. Pajak Daerah dan Retribusi Daerah, Jakarta. Rajawali Pers.

Suartini, Ni Nyoman. 2013. Pengaruh Jumlah Kunjungan Wisatawan, Pajak Hiburan, Pajak Hotel, dan Restoran Terhadap Pendapatan Asli Daerah di Kabupaten Gianyar. Universitas Udayana. http://www.ojs.unud.ac.id/index.p hp/EEB (Diakses 9 Februari 2016).

Undang-Undang Republik Indonesia Nomor 9 Tahun 1990 tentang Kepariwisataan.

Undang-Undang No. 32 Tahun 2004 tentang Pemerintahan Daerah.

Yoeti, Oka A. 1996. Pengantar Ilmu Pariwisata. Bandung. PT. Angkasa. 